\title{
Pembangunan Aplikasi E-Magang Perguruan Tinggi dengan Memanfaatkan SDLC SCRUM pada Agile Project Management
}

\author{
Prio Kustanto ${ }^{1, *}$, R. Wisnu P. Pamungkas ${ }^{1}$, Ahmad Fathurrozi ${ }^{1}$ \\ ${ }_{1}^{1}$ Program Studi Informatika; Fakultas IImu Komputer Universitas Bhayangkara Jakarta \\ Raya; Jalan Raya Perjuangan No.81 Marga Mulya Bekasi Utara Jawa Barat, telp/fax (021) \\ 88955882; e-mail: pkustanto@dsn.ubharajaya.ac.id, wisnu.prio@dsn.ubharajaya.ac.id, \\ fathur@dsn.ubharajaya.ac.id \\ * Korespondensi: e-mail: pkustanto@dsn.ubharajaya.ac.id.
}

Diterima: 28 Juni 2021; Review: 28 Juni 2021; Disetujui: 29 Juni 2021; Diterbitkan: 4 Juli 2021

\begin{abstract}
Higher Education facilitates the process of Internship students through several stages, which can be taken by students after fulfilling the requirements. The Process of Internship, starting with making an official letter of submission to the company where the internship is accompanied by the submission of proposals internships until the implementation of Internship Work in the company is completed. After the internship process is completed students then make a report Internship. Readiness of Study Program to the Faculty in managing the process of implementation of internship work vary. Especially readiness when the Study Program enrolls students until obtaining the scheduling of the seminar report Internship.

Universities that have fewer students may not be a problem. But if universities have a large number of Faculties and Study Programs, so the number of active students owned is also a lot, this can be the first step of the complexity of a system. The problems that arise are conflicting schedules of supervisors, examiners and rooms.

To facilitate the implementation of the process, e-Magang application is made to help the application process of Internship. The e-Internship application is built with the phase flow of the Scrum SDLC method in Project Management.
\end{abstract}

Keywords: e-Internship, Application, SDLC, Scrum, Project Management

\begin{abstract}
Abstrak
Perguruan Tinggi memfasilitasi proses Magang Kerja mahasiswa melalui beberapa tahapan, yang dapat ditempuh oleh mahasiswa setelah memenuhi persyaratannya. Proses Magang Kerja/Kerja Praktek, dimulai dengan membuat surat resmi pengajuan ke perusahaan tempat magang disertai dengan pengajuan proposal Magang Kerja sampai dengan pelaksanaan Magang Kerja/Kerja Praktek di perusahaan tersebut selesai. Setelah proses magang kerja selesai mahasiswa kemudian membuat laporan Magang Kerja/Kerja Praktek.Kesiapan Program Studi hingga Fakultas dalam mengelola proses pelaksanaan Magang kerja/Kerja praktek berbeda-beda. Utamanya kesiapan pada saat Program Studi mendaftarkan mahasiswa hingga memperoleh penjadwalan seminar laporan Magang Kerja/Kerja Praktek.

Perguruan Tinggi yang memiliki mahasiswa dengan jumlah sedikit, mungkin tidak menjadi masalah. Tetapi jika Perguruan Tinggi memiliki jumlah Fakultas dan Program Studi yang banyak, sehingga jumlah mahasiswa aktif yang dimiliki juga banyak, hal ini bisa menjadi langkah awal dari terjadinya kompleksitas sebuah sistem. Permasalahan yang muncul adalah diantaranya terjadi bentrok jadwal sidang dosen pembimbing, penguji dan ruangan.
\end{abstract}


Untuk mempermudah pelaksanaan proses tersebut, aplikasi e-Magang dibuat untuk membantu tahapan proses pengajuan Magang Kerja/Kerja Praktek. Aplikasi e-Magang dibangun dengan alur tahapan metode SDLC Scrum dalam Pengelolaan Proyek (Project Management).

Kata kunci: e-Magang, Aplikasi, SDLC, Scrum, Project Management

\section{Pendahuluan}

Perguruan Tinggi baik yang bermentuk Universitas hingga Sekolah Tinggi memiliki Jurusan/Program Studi. Baik perguruan tinggi yang berskala kecil maupun yang berskala besar hingga Internasional, semua akan menjadikan pengelolaan mahasiswa yang berjumlah besar sebagai salah satu persyaratan wajib(mandatory) yang tidak boleh dilewatkan.

Salah satu Perguruan Tinggi swasta yang dapat dijadikan percontohan dalam penelitian adalah Universitas Bhayangkara Jakarta Raya yang memiliki 7(tujuh) Fakultas dan 14(empat belas) Program Studi. Berdasar laporan Rektor pada acara wisuda Universitas Bhayangkara Jakarta Raya bulan Oktober tahun 2019, jumlah lulusan tahun 2019 adalah 1.192 mahasiswa yang terdiri dari 1.148 orang mahasiswa program sarjana(S1) dan 44 orang mahasiswa program Magister(S2)(Universitas Bhayangkara Jakarta Raya, 2019). Setiap mahasiswa, dalam proses perkuliahannya untuk lulus telah melalui beberapa tahapan, yaitu diantaranya proses magang dan skripsi. Makin banyak jumlah mahasiswa, akan makin butuh waktu pada setiap proses pelaksanaannya, terutama pada pengelolaan Magang Kerja/Kerja Praktek dan Skripsi.

Berdasar latarbelakang tersebut, maka diperlukan sebuah aplikasi yang mendukung sebuah sistem pelaksanaan Magang Kerja/Kerja Praktek di sebuah Perguruan Tinggi bila memiliki jumlah mahasiswa hingga ribuan dalam satu angkatan tahun ajaran.

Proses Magang secara sederhana akan terkait dengan beberapa pihak terkait sebagai Stakeholder. Diantaranya adalah; Mahasiswa, Kepala Program Studi, Sekretariat Program Studi, Dekan, Sekretariat Fakultas dan Dosen. Alur proses kegiatan secara sederhana gambaran proses awalnya adalah:

1. Mahasiswa membuat Pengajuan Proposal Magang, dan Perusahaan tempat magang,

2. Dengan memenuhi persayaratan administrasi pengajuan diproses melalui persetujuan Kepala Program Studi.

3. Berkas administrasi diterima bagian Sekretariat Program Studi dan / atau Fakultas

4. Dilanjutkan melalui persetujuan Dekan

5. Informasi kembali ke Mahasiswa sebagai proses konfirmasi penjadwalan Jadwal Bimbingan hingga Jadwal Sidang Judul/Proposal.

Dari proses tersebut, Kepala Program Studi sudah dapat menunjuk dosen sebagai pembimbing, sehingga pencatatan dan penjadwalan bimbingan mahasiswa dengan dosen secara aplikatif hingga diakhir bimbingan yang disetujui oleh dosen pembimbing. Mahasiswa terdaftar dalam penjadwalan Seminar/Sidang Magang Kerja, mengetahui jadwal, siapa dosen pengujinya dan ruangan sidangnya. Penyimpanan berkas digital akan memudahkan proses pekerjaan dari progam studi, fakultas, mahasiswa dan dosen. 
Setelah siklus tahapan sidang proposal judul laporan magang berakhir, data dan informasi dapat dilanjutkan untuk digunakan sebagai data dan informasi di siklus seminar/sidang magang, dan seterusnya hingga digunakan sebagai data dan informasi skripsi. Hal tersebut akan memudahkan program studi dan fakultas dalam mencatat dan melaporkan secara administratif untuk kebutuhan mahasiswa, dosen, dan institusi.

Penelitian ini menggambarkan bagaimana membangun sebuah aplikasi sebagai alat dalam sistem magang kerja, melalui tahap pengajuan hingga hasil laporan dengan memanfaatkan metode SDLC Scrum dalam mengelola kegiatan menjadi sebuah Pegelolaan Proyek (Project Management).

Tujuan dari penelitian diantaranya adalah;

a. Membuat Sistem sederhana (Menyederhanakan alur Sistem e-Magang)

b. Menerapkan SDLC Scrum pada pelaksanaan pengelolaan Proyek (Project Management). (Pamungkas \& Khalida, 2019)

c. Membuat Aplikasi e-Magang yang dapat digunakan sebagai alat media penyimpanan dokumen secara digital, sehingga mudah dalam penyimpanan, penyediaan, penelusuran dan pencetakan dokumen.

Penelitian ini diharapkan memberikan manfaat dalam menyusun alur kegiatan kerja praktek/magang kerja dan dapat dikembangkan agar menjadi bagian dari sistem informasi pengelolaan kegiatan magang kerja yang baik.

\section{Metode Penelitian}

Penelitian dan pembangunan aplikasi dilakukan dengan metode SDLC(System Development Life Cycle) Scrum. Sehingga aplikasi ini dapat ditunjukan ke user di tahap awal dalam kurun waktu relatif cepat. Adapun tahapan SDLC Scrum (Schwaber \& Sutherland, 2017) digambarkan sebagai berikut;

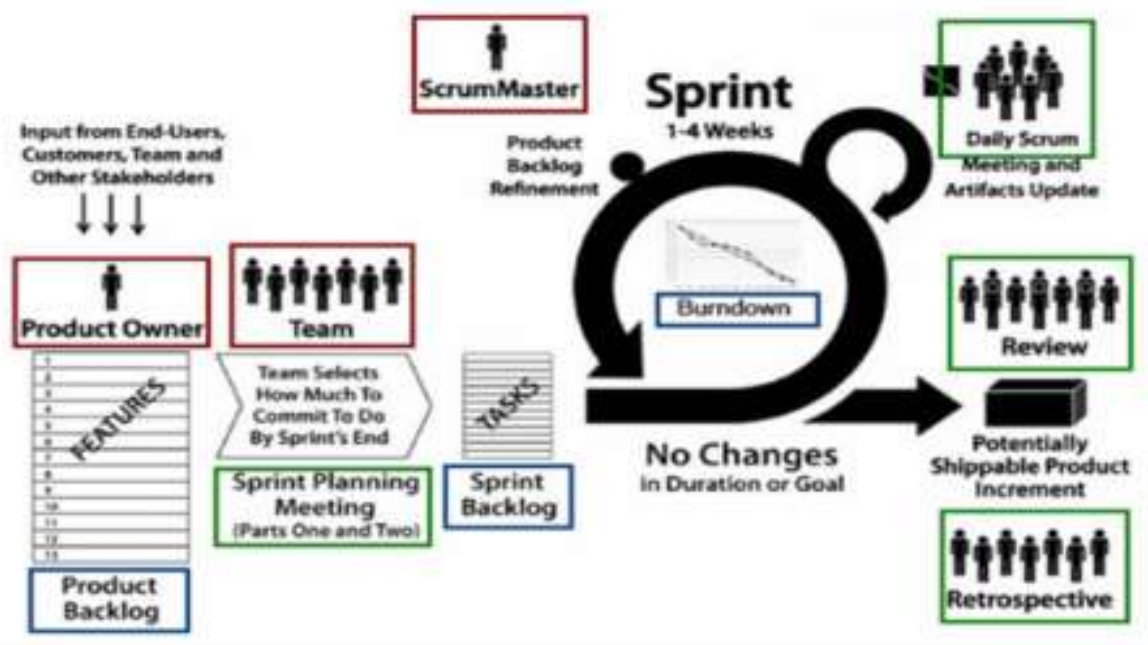

Sumber:(Hutasoit, 2016)

Gambar 1. Tahapan Scrum 
Tahapan SDLC Scrum seperti yang digambarkan pada gambar 1. di atas urutannya dapat dijelaskan sesuai dengan urutan scrum phases and process (English, 2018), sebagai berikut :

1. Inisiasi (Initiate)

1.1. Create Project Vision

1.2. Identify Scrum Master dan Stakeholders

1.3. Form Scrum Team

1.4. Develop Epics

1.5. Create Prioritized Product Backlog

1.6. Conduct Release Planning

2. Perencanaan dan perkiraan (Plan and Estimate)

2.1. Create User Stories

2.2. Approve, Estimate and Commit User Stories

2.3. Create Tasks

2.4. Estimate Tasks

2.5. Create Sprint Backlog

3. Implementasi (Implement)

3.1. Create Deliverable

3.2. Conduct Daily Standup

3.3. Groom Prioritized Product Backlog

4. Review and Retrospect

4.1. Convene Scrum of Scrums

4.2. Demonstrate and Validate Sprint

4.3. Retrospect Sprint

5. Release

5.1. Ship Deliverabel

5.2. Retrospect Project

\section{Hasil dan Pembahasan}

Pembahasan dan hasil penelitian dijabarkan dalam tiga bagian pembahasa yaitu Alur sistem e-Magang, Manajemen proyek dengan Scrum, dan Rancangan aplikasi e-Magang seperti berikut;

\subsection{Alur Sistem e-Magang}

Alur sistem e-Magang dimulai dari mahasiswa yang mendaftar lewat form magang. Jika mahasiswa sudah menginput pendaftaran magang, maka dosen PA akan dapat notifikasi dan bisa melakukan pengecekan terhadap data pendaftaran mahasiswa magang. Setelah data lengkap dan syarat terpenuhi, maka dosen Penasehat Akademik dapat memverifikasinya. 
Setelah diverifikasi oleh dosen Penasehat Akademik maka surat pengantar magang dapat dicetak.

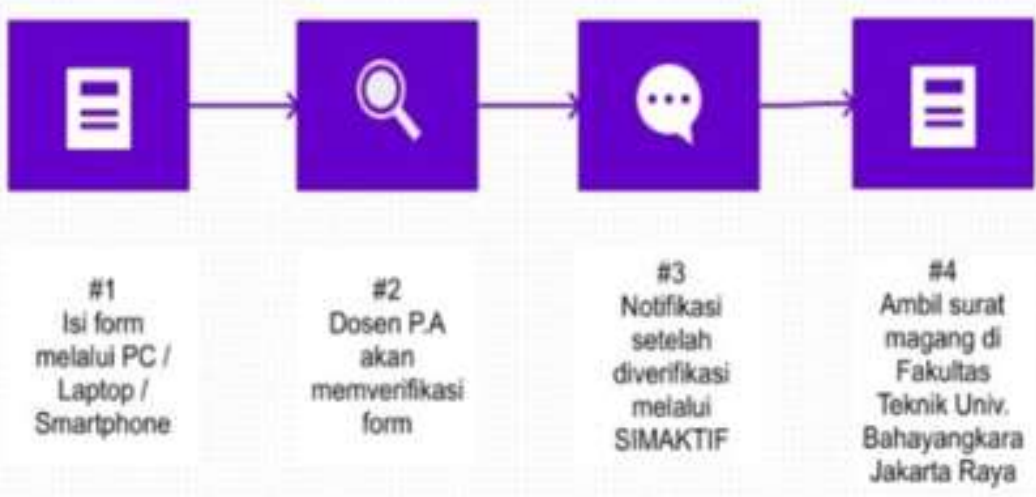

Sumber: Hasil Penelitian (2021)

Gambar 2. Alur system e-Magang

Pada Gambar 2. menunjukan alur sistem e-Magang yang diawalai dengan tahapan input data mahasiswa sampai dengan output dicetaknya surat magang.

\subsection{Manajemen Proyek dengan SDLC Scrum}

Pada Scrum digunakan perencanaan-perencanaan yang terpecah-pecah menjadi kecilkecil untuk kemudian diselesaikan di dalam setiap sprint. Scrum telah sukses dipakai oleh perusahaan-perusahaan besar seperti Google, Amazon dan SalesForce. Di dalam sebuah tim scrum, biasanya berjumlah kecil orang maksimal 5 orang. tim kecil akan melakukan proses analisis pekerjaan-pekerjaan yang harus dilakukan untuk kemudian memberikan nilai dan mengelompokkan pekerjaan-pekerjaan tersebut menjadi grup-grup. Dalam setiap grup pekerjaan, diselesaikan dalam sprint yang dihitung antara 1-2 minggu pengerjaan. Di akhir pengerjaan, tim akan mendemokan hasilnya untuk dilakukan evaluasi dan mendapatkan umpan balik. Selanjutnya, tim akan menentukan kembali grup pekerjaan yang akan di sprintkan lagi pada tahap berikutnya. Begitu terus sampai produk atau proyek selesai dikerjakan.

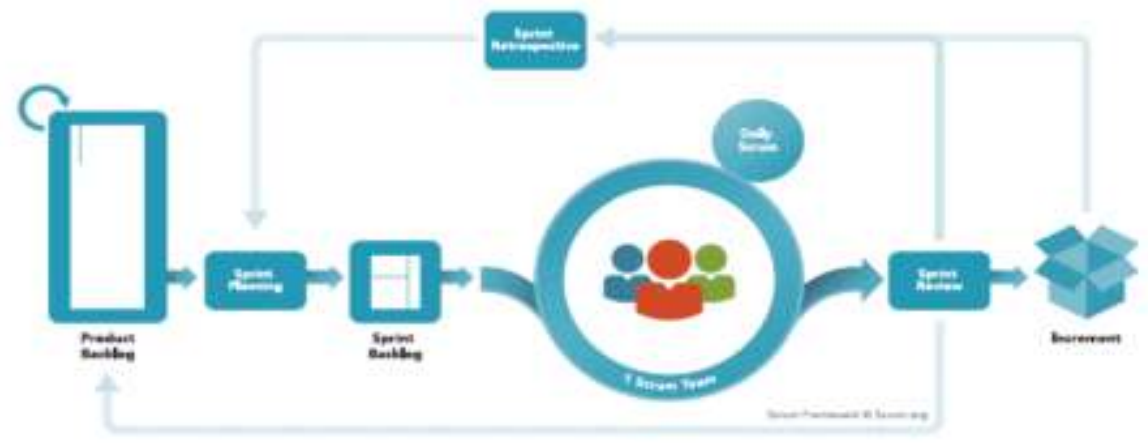

Sumber: (Gamelab Indonesia, 2019)

Gambar 3. Kerangka kerja Scrum 
Pada gambar 3. Menjelaskan tujuh langkah penting dalam scrum (Gamelab Indonesia, 2019) sebagaimana berikut;

\section{Kumpulkan Backlog}

Tim scrum akan mengumpulkan pekerjaan-pekerjaan yang harus dilakukan. mendaftar semua pekerjaan yang harus dilakukan, berikan judul tetapi tidak usah terlalu detail. Listing harus mencakup semua pekerjaan dan jangan sampai ada yang terlewat. Daftar ini disebut sebagai backlog.(Kurniawan \& Sani, 2019) Format untuk setiap pekerjaan harus mencakup Who (siapa yang mengerjakan), What (apa yang dikerjakan) dan Why (mengapa harus diselesaikan).

2. Lakukan Estimasi secara relatif

Backlog yang ada kita berikan estimasi secara relative. Gunakan nilai fibonacci untuk memberikan tingkat kesulitan untuk setiap pekerjaan. Fibonacci adalah seperti angka berikut: 1, 2, 3, 5, 8, 13 dan seterusnya. Fibonacci memungkinkan estimasi yang lebih realistis karena pekerjaan semakin rumit membutuhkan waktu yang semakin lama. Setiap pekerjaan berikan nilai fibonacci berdasarkan tingkat kesulitannya sebagai nilai poin.

3. Lakukan Sprint

biasanya dilakukan antara 1-2 minggu. Untuk sprint yang pertama sangatlah penting. Pilih pekerjaan-pekerjaan dari backlog kemudian lakukan sprint untuk menyelesaikan pekerjaan-pekerjaan tersebut. (Adi, 2015)

\section{Visibility dan Burndown Chart}

untuk setiap backlog yang dipilih tersebut kita bisa memisahkannya ke dalam 1 kolom tabel bernama TODO. Apabila ada anggota tim yang sedang mengerjakan pekerjaan tersebut, pindah ke dalam kolom DOING. Dan apabila ada anggota tim yang selesai mengerjakan pekerjaan tersebut, pindah ke dalam kolom DONE. (Kharisma \& Santoso, 2020)

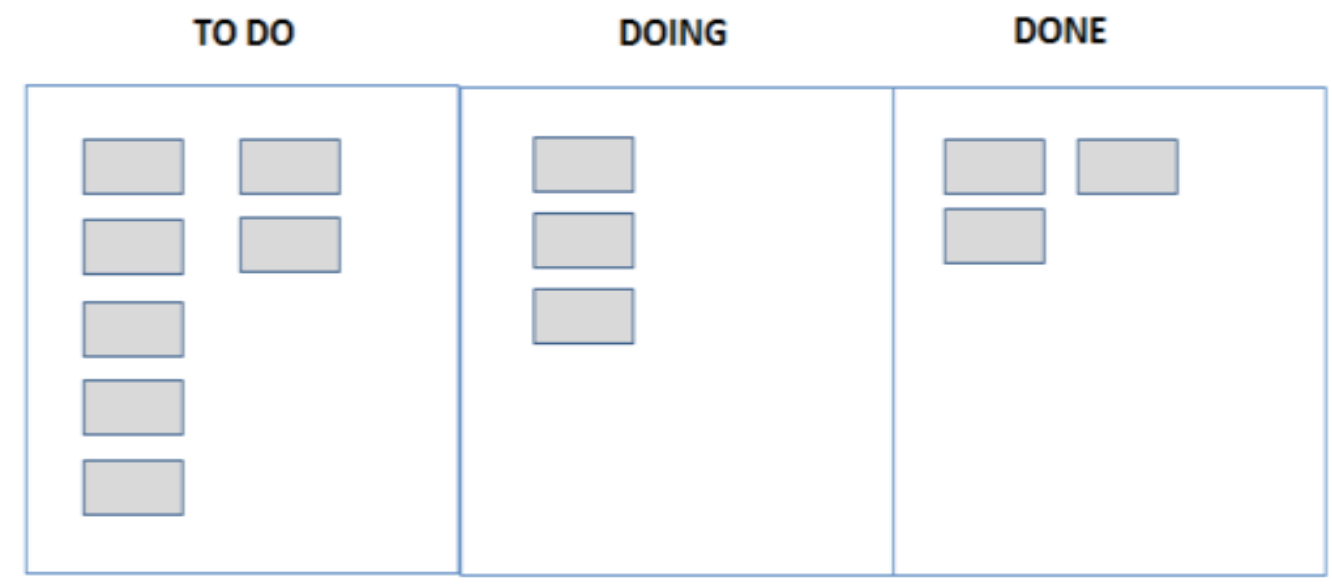

Sumber: (Gamelab Indonesia, 2019)

Gambar 4. Sprint Backlog 


\section{Daily Standup Meetings}

Hal penting yang harus ada di dalam scrum adalah meeting singkat selama 15 menit dengan cara berdiri untuk setiap tim sprint. Biasanya dipimpin oleh fasilitator untuk kemudian setiap anggota akan memberitahukan yesterday - apa yang dilakukan kemarin? (Ruseno, 2019)

\section{Demo MVP}

Pada akhir setiap sprint tim akan mendemokan MVP (Minimum Viable Product) kepada customer atau product owner atau pemegang keputusan. Hal ini penting untuk mendapatkan feedback secara cepat sehingga banyak keputusan yang bisa diambil melalui MVP tersebut.

\section{Evaluation}

Perlu dilakukan tim sprint pada tahapan akhir adalah melakukan evaluasi beberapa hal seperti:

Went well --> apa saja yang berjalan dengan baik?

Not well --> apa saja yang tidak berjalan dengan baik?

Improvements --> apa saja yang perlu diperbaiki di sprint berikutnya?

\subsection{Rancangan Aplikasi e-Magang}

Tampilan rancangan Sistem Informasi Magang Kerja (e-Magang) dapat digambarkan sebagai berikut;

\subsubsection{Halaman login}

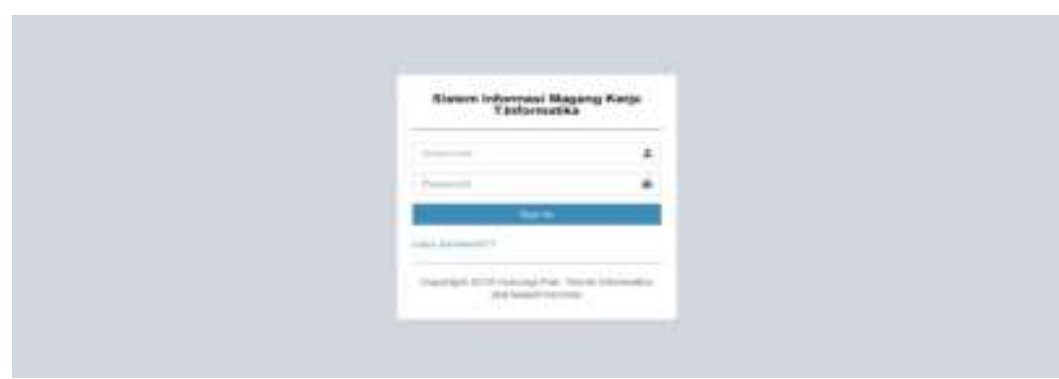

Sumber: Hasil Penelitian (2021)

Gambar 5. Halaman Login

\subsubsection{Tampilan notifikasi}

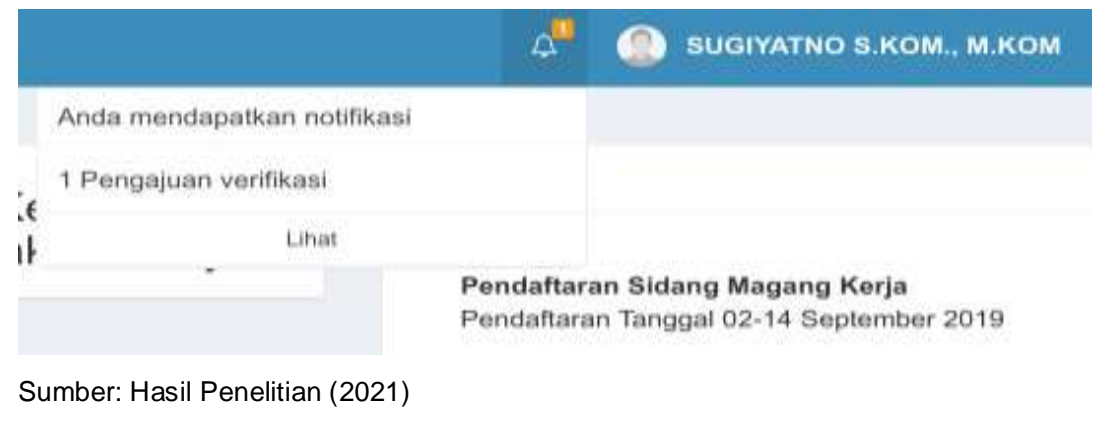

Gambar 6. Tampilan Mendapat Notifikasi 


\subsubsection{Tampilan admin}

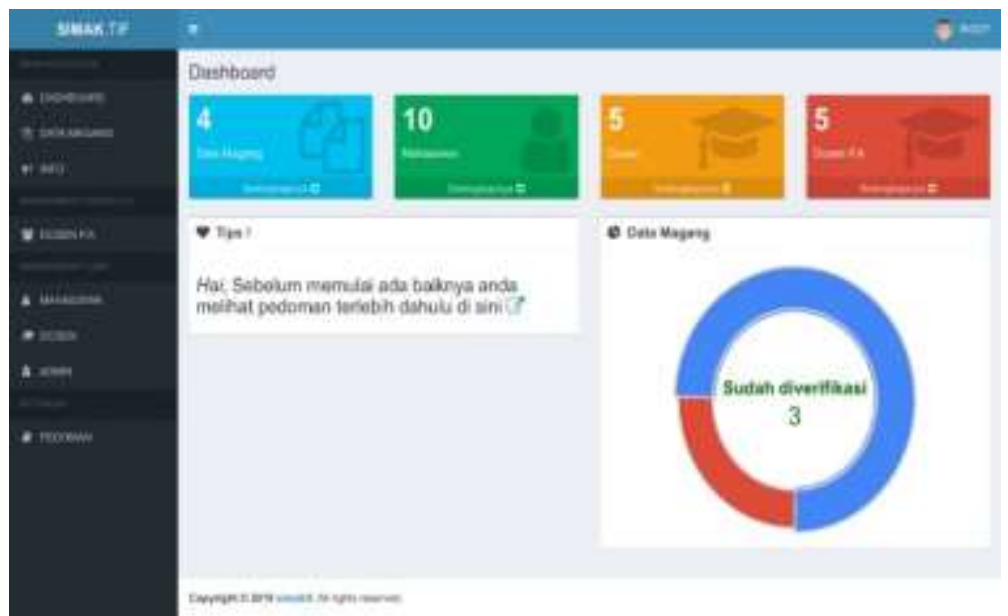

Sumber: Hasil Penelitian (2021)

Gambar 7. Halaman Dashboard

\subsubsection{Halaman data magang}

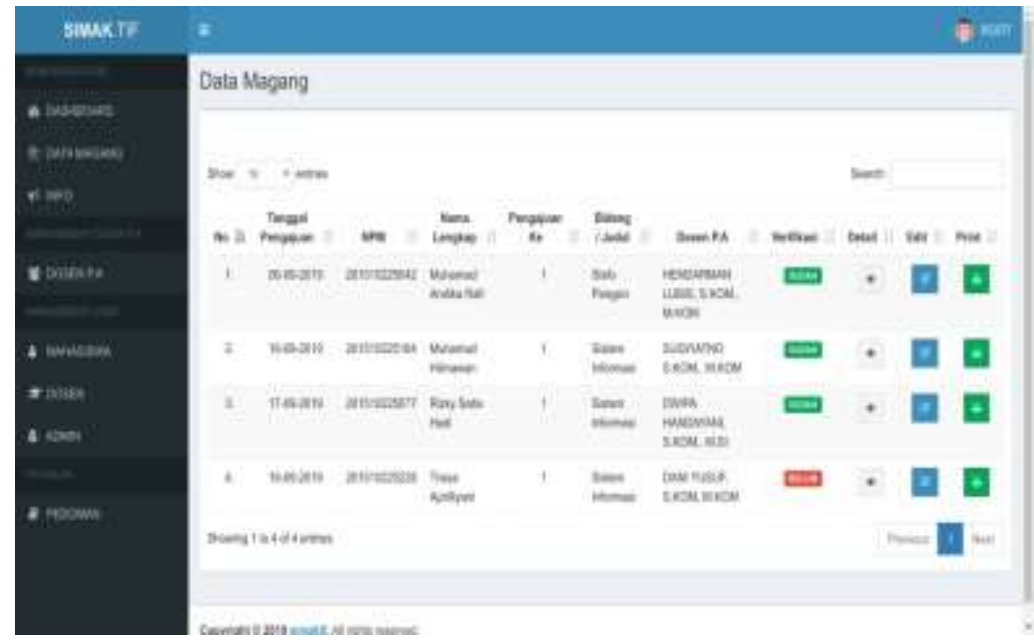

Sumber: Hasil Penelitian (2021)

Gambar 8. Halaman Data Magang

\subsubsection{Halaman print data magang}

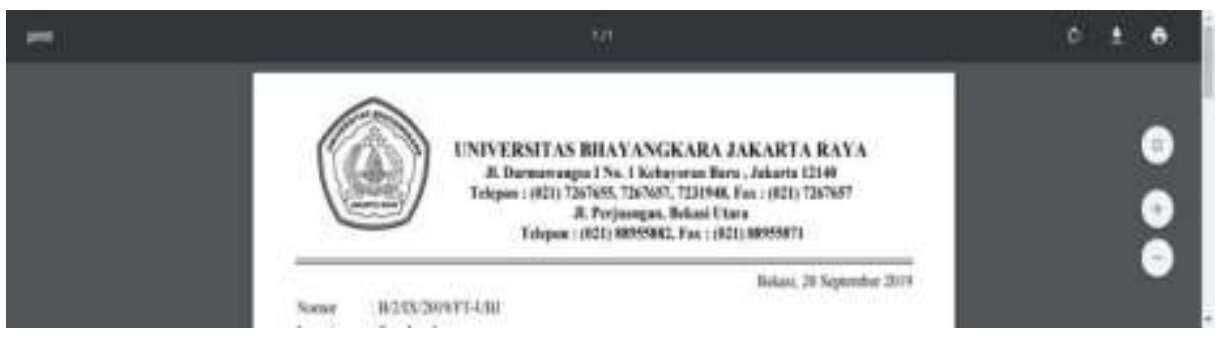

Sumber: Hasil Penelitian (2021)

Gambar 9. Halaman Print Data Magang 


\subsubsection{Halaman info}

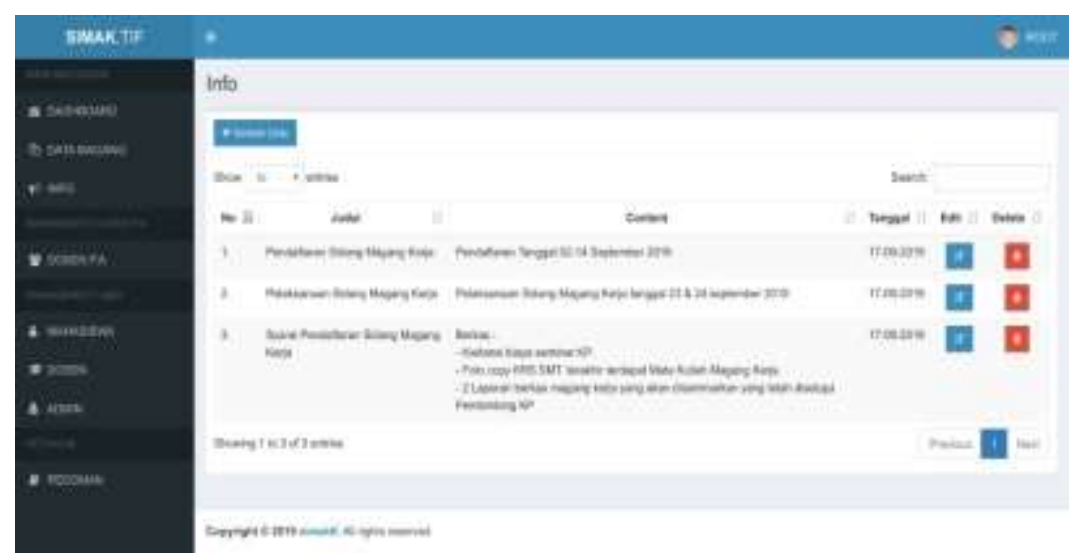

Sumber: Hasil Penelitian (2021)

Gambar 10. Halaman Info

\subsubsection{Halaman dosen pembimbing akademik}

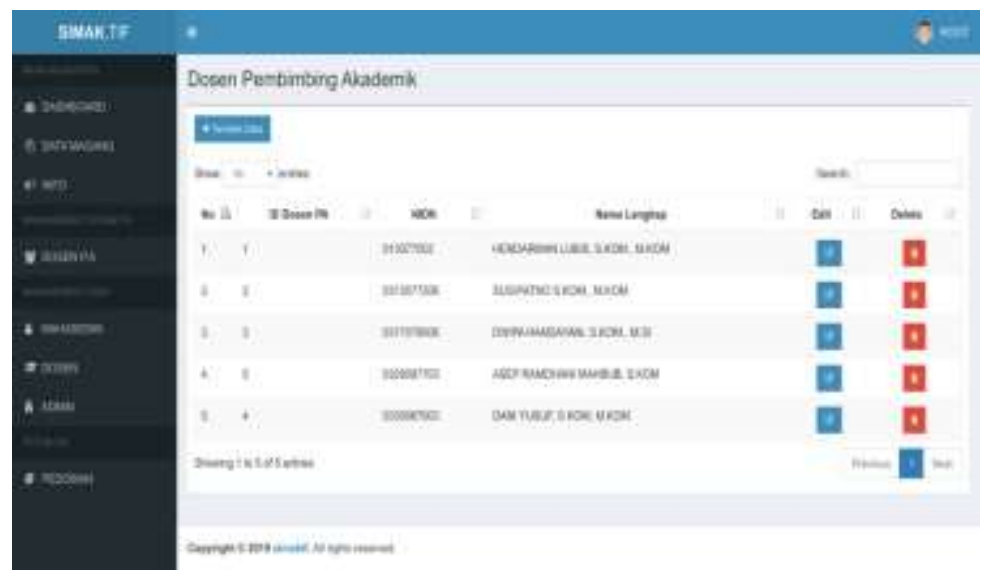

Sumber: Hasil Penelitian (2021)

Gambar 11. Halaman Dosen Pembimbing Akademik

\subsubsection{Halaman dosen}

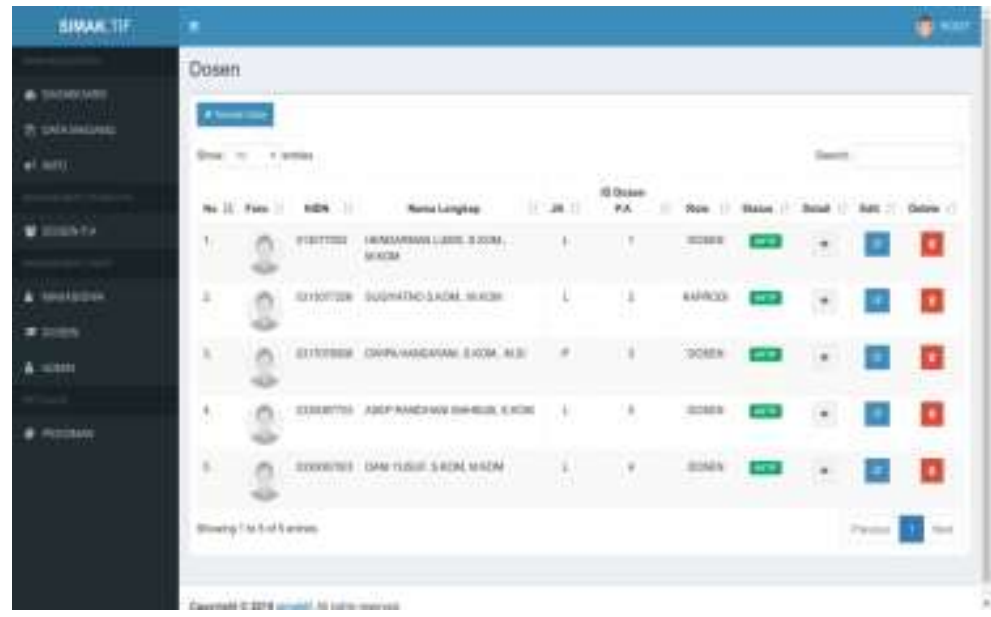

Sumber: Hasil Penelitian (2021)

Gambar 12. Halaman Dosen 


\subsubsection{Halaman mahasiswa}

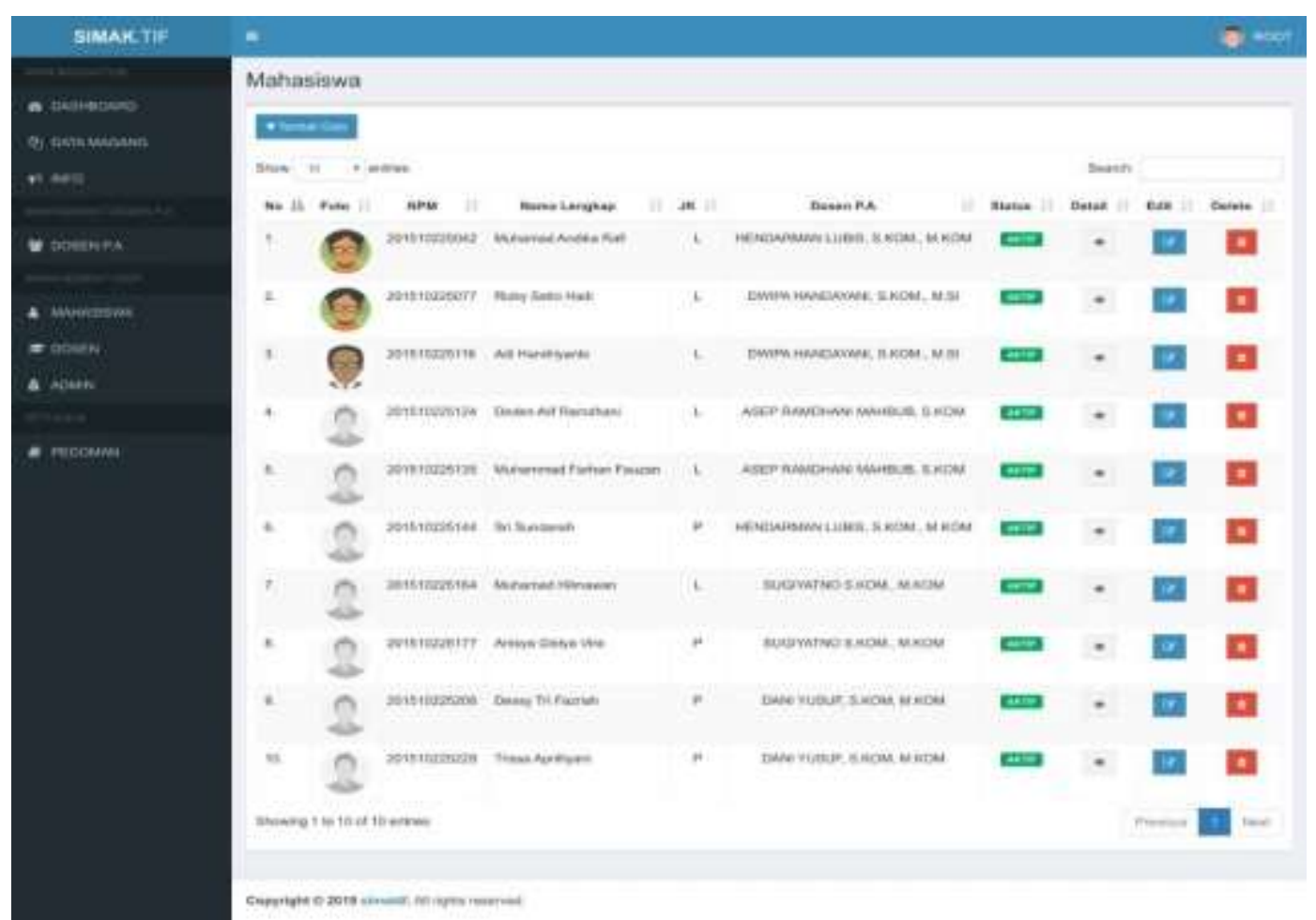

Sumber: Hasil Penelitian (2021)

Gambar 13. Halaman Mahasiswa

\subsubsection{Halaman admin}

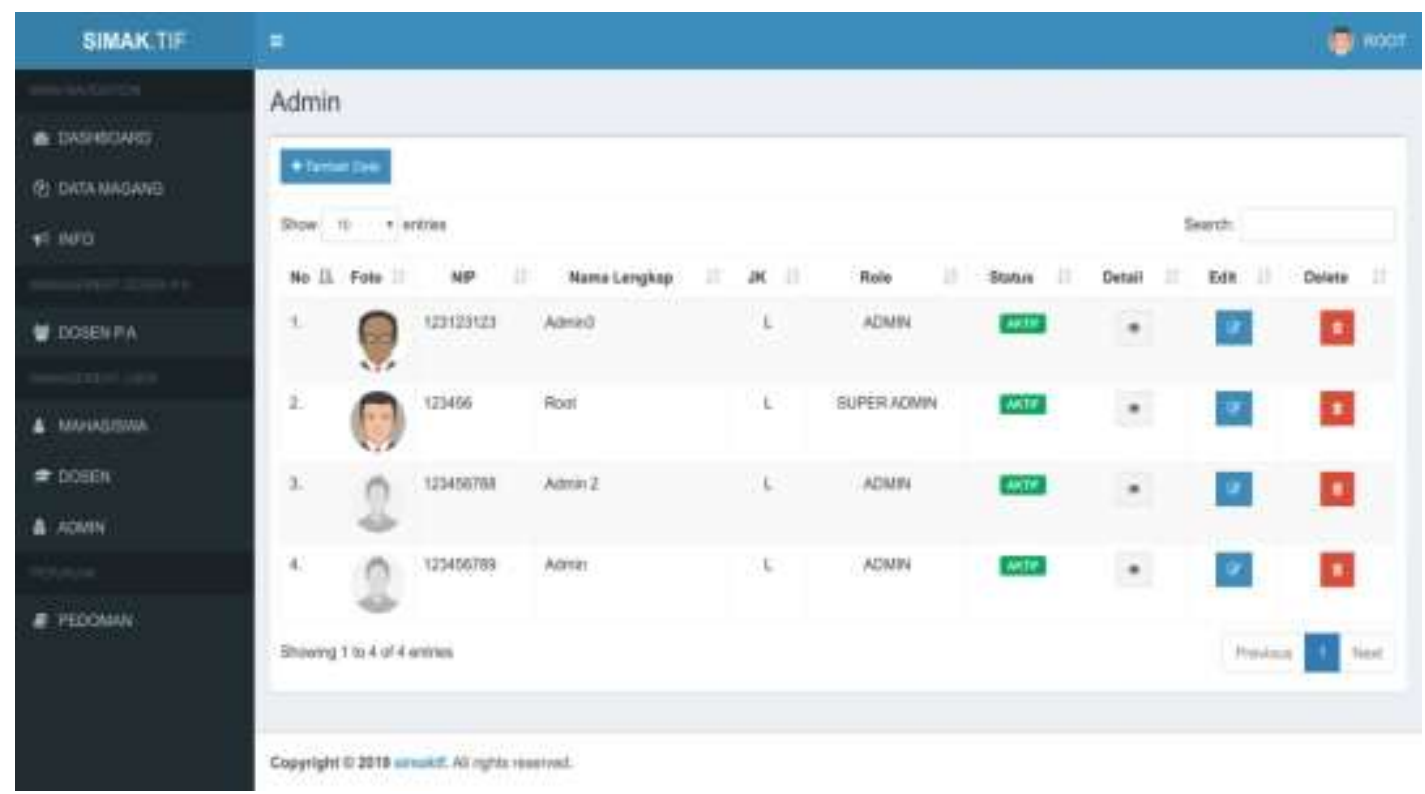

Sumber: Hasil Penelitian (2021)

Gambar 14. Halaman Admin 


\subsubsection{Profil Admin}

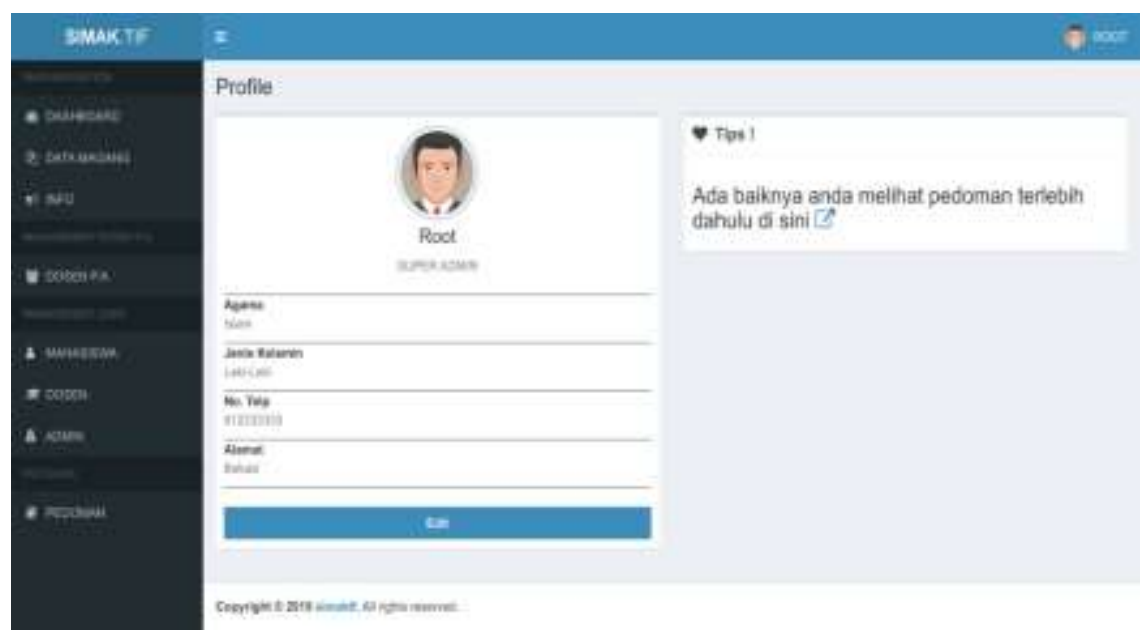

Sumber: Hasil Penelitian (2021)

Gambar 14. Halaman Profile Admin

\subsubsection{Tampilan dosen}

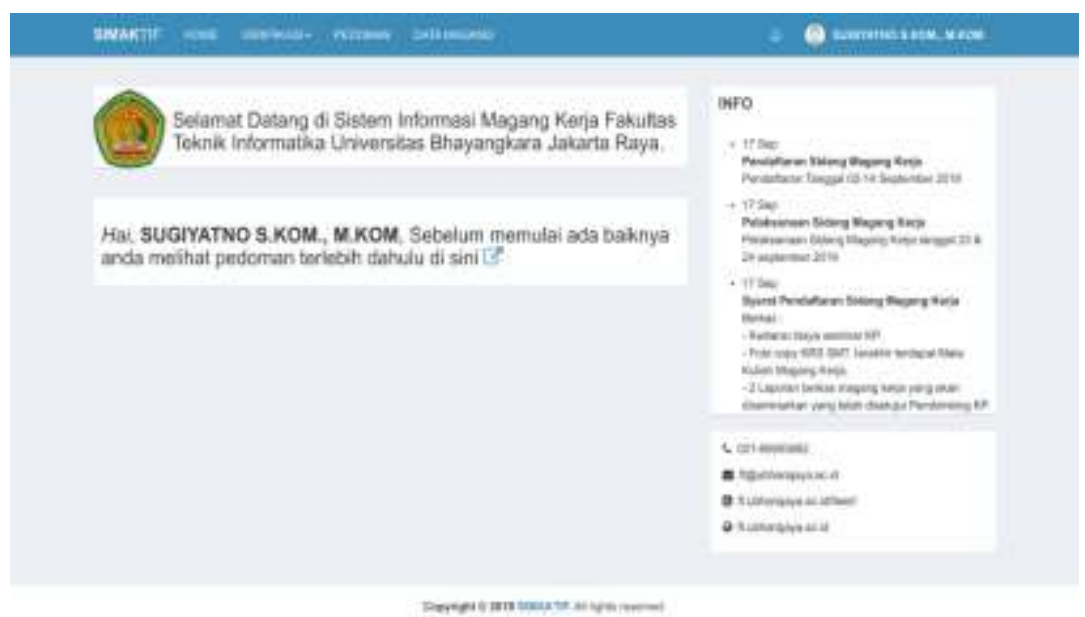

Sumber: Hasil Penelitian (2021)

Gambar 15. Halaman Home Dosen

\subsubsection{Halaman verifikasi form magang}

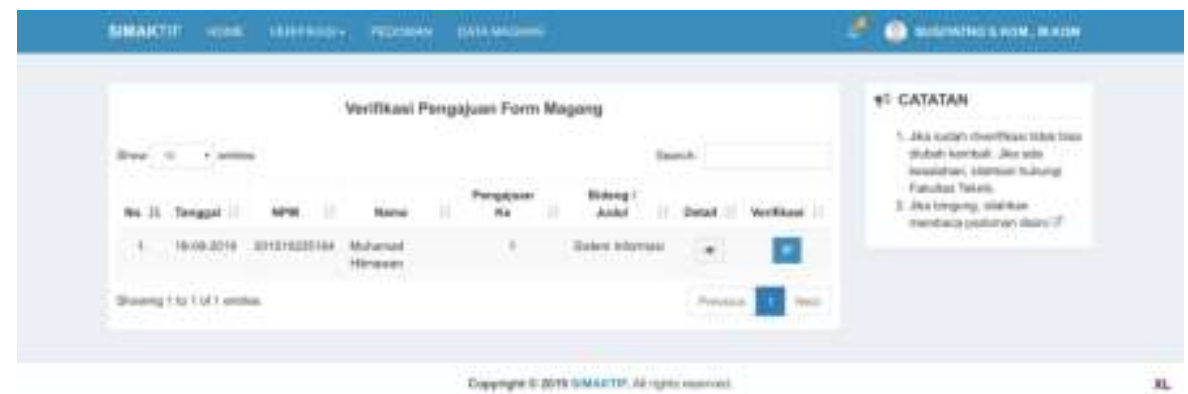

Sumber: Hasil Penelitian (2021)

Gambar 16. Halaman Verifikasi Form Magang 


\subsubsection{Halaman data magang}

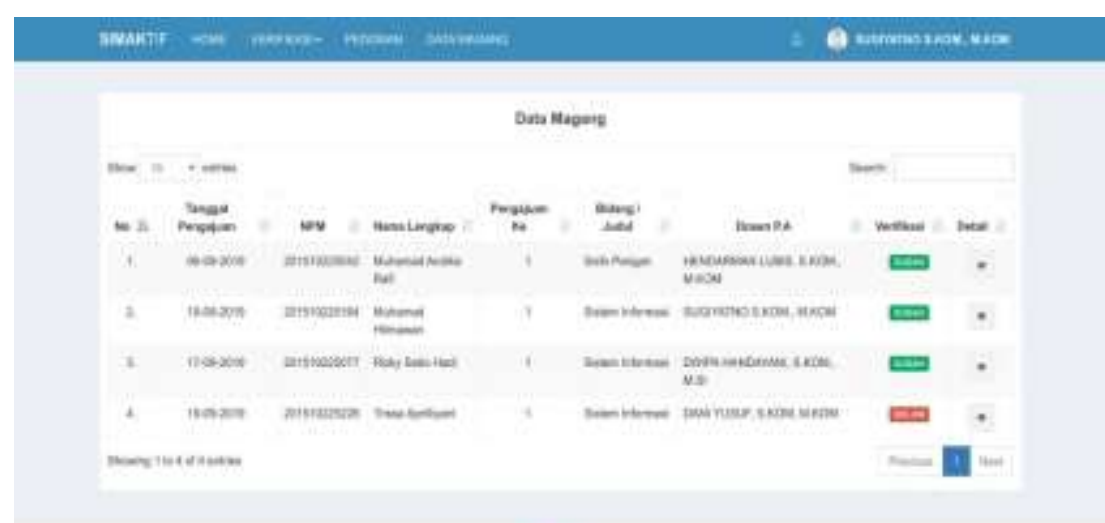

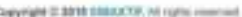

Sumber: Hasil Penelitian (2021)

Gambar 17. Halaman Data Magang

\subsubsection{Tampilan mahasiswa}

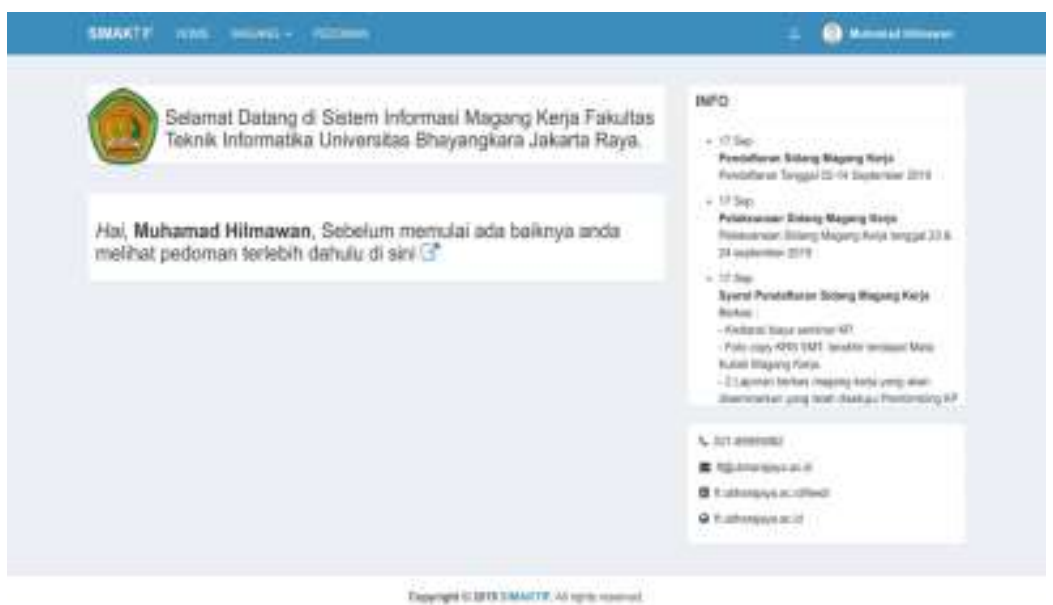

Sumber: Hasil Penelitian (2021)

Gambar 18. Halaman Home Mahasiswa

\subsubsection{Halaman riwayat pengajuan form magang}

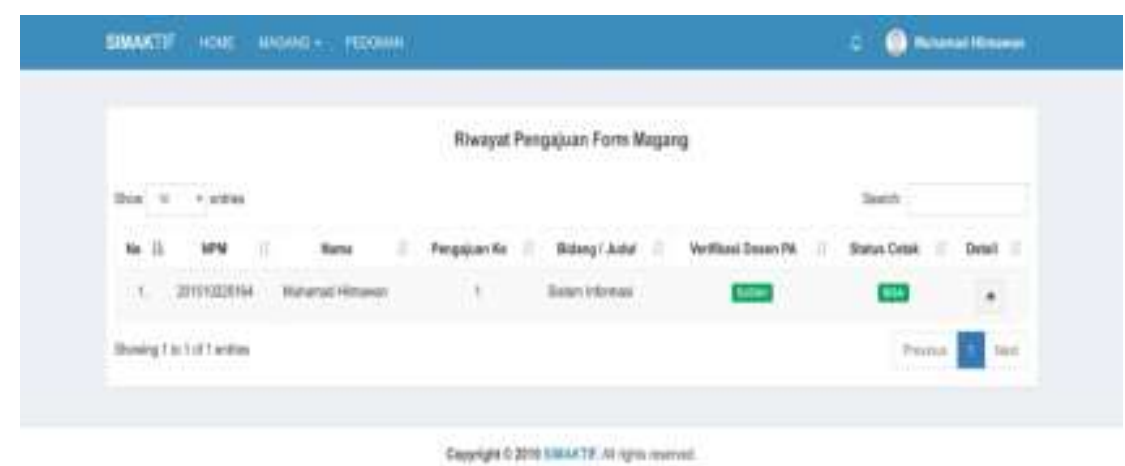

Sumber: Hasil Penelitian (2021)

Gambar 19. Halaman Riwayat Pengajuan Form Magang 


\subsubsection{Halaman pedoman}

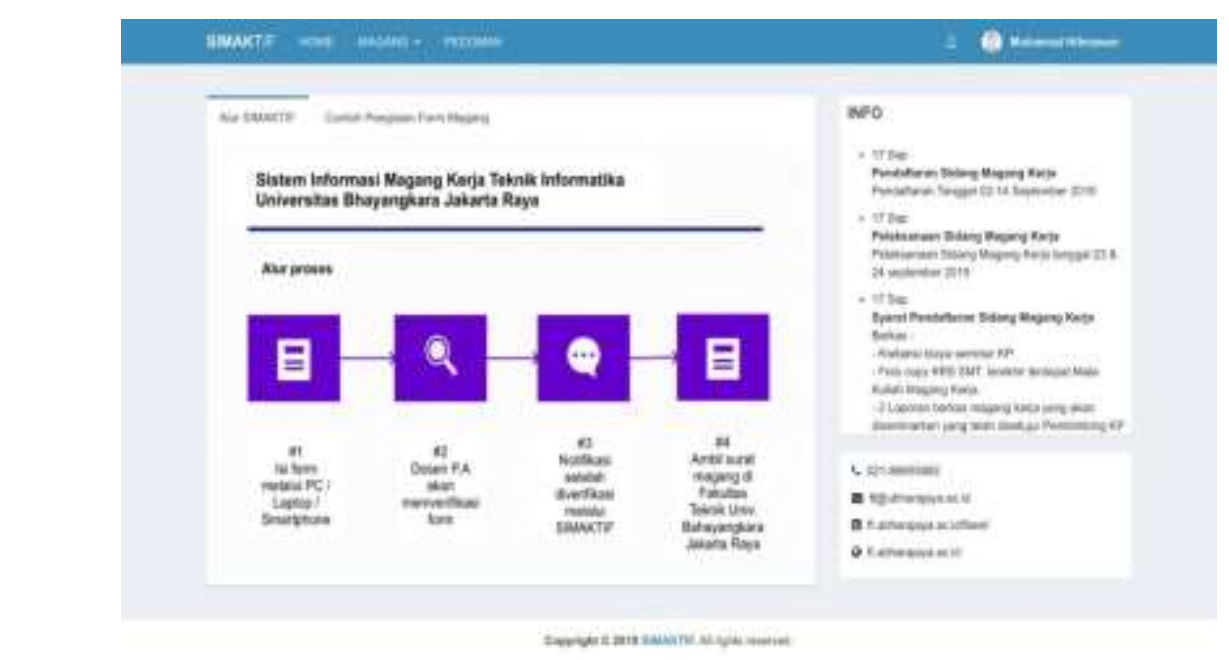

Sumber: Hasil Penelitian (2021)

Gambar 20. Halaman Pedoman Alur sistem

\section{Kesimpulan}

Pembangunan aplikasi e-Magang dapat memberikan dampak yang baik terhadap pengelolaan kegiatan magang kerja/kerja praktek, diantaranya;

1. Memperkaya pembahasan pembangunan aplikasi pengelolaan kegiatan magang menggunakan metodolgy scrum dalam pelaksanaan project management.

2. Membentuk dasar alur prosedur standar operasional (SOP) pengelolan kegiatan Magang kerja/kerja praktek, sehingga dapat digunakan sebagai alur pembangunan aplikasi berbasis web, e-Magang.

3. Membangun aplikasi e-Magang yang ringan, mudah digunakan, efektif dan efisien bagi perguruan tinggi baik yang memiliki jumlah mahasiswa sedikit ataupun besar.

\section{Daftar Pustaka}

Adi, P. (2015). Scrum Method Implementation in a Software Development Project Management. International Journal of Advanced Computer Science and Applications, 6(9), 198-204. https://doi.org/10.14569/ijacsa.2015.060927

English, L. (2018). Webinar on Introduction to Scrum and Agile and Training for Scrum Fundamentals Certified (SFC ${ }^{T M}$ ) Certification.

Gamelab Indonesia. (2019). Manajemen Proyek Secara Efektif Menggunakan Scrum. Https:/Www.Gamelab.ld/. https://www.gamelab.id/news/164-manajemen-proyek-secaraefektif-menggunakan-scrum\#

Hutasoit, F. (2016). Apa yang dimaksud dengan Scrum pada pengembangan perangkat lunak? 
Https://Www.Dictio.ld. https://www.dictio.id/t/apa-yang-dimaksud-dengan-scrum-padapengembangan-perangkat-lunak/2213

Kharisma, B., \& Santoso, N. (2020). Pengembangan Aplikasi Manajemen Proyek Perangkat Lunak Kolaboratif Menggunakan Scrum. Jurnal Pengembangan Teknologi Informasi Dan IImu Komputer (J-PTIIK) Universitas Brawijaya, 4(3), 723-732.

Kurniawan, I., \& Sani, R. R. (2019). Pemodelan SCRUM dalam Pengembangan Sistem Informasi Kesehatan pada Klinik Ar-Rokhim Sragen Kabupaten Sragen. JOINS (Journal of Information System), 4(1), 76-86. https://doi.org/10.33633/joins.v4i1.2530

Pamungkas, R. W. P., \& Khalida, R. (2019). Manajemen Proyek Agile dengan Pendekatan Metode Scrum sebagai Peningkatan Layanan Berkelanjutan Perusahaan. Pamungkas, $R$. W. P., \& Khalida, R. (2019). Manajemen Proyek Agile Dengan Pendekatan Metode Scrum Sebagai Peningkatan Layanan Berkelanjutan Perusahaan. Prosiding SISFOTEK, 187194. Http://Seminar.laii.or.Id/Index.Php/SISFOTEK/Article/View/124Prosiding SISF, 3(1), 187-194. http://seminar.iaii.or.id/index.php/SISFOTEK/article/view/124

Ruseno, N. (2019). Implementasi Scrum pada Pengembangan Aplikasi Sistem Reservasi Online Menggunakan PHP. Gerbang, 9(1), 8-15. http:/jurnal.stmik.banisaleh.ac.id/index.php/JIST/article/view/61

Schwaber, K., \& Sutherland, J. (2017). The Scrum Guide: The Definitive The Rules of the $\begin{array}{llll}\text { Game. Scrum.Org and Scrumlnc, November, } & 19 .\end{array}$ http://www.scrumguides.org/docs/scrumguide/v1/Scrum-Guide-US.pdf

Universitas Bhayangkara Jakarta Raya. (2019). Wisuda Sarjana \& Magister Semester Genap T.A. 2018/2019 Universitas Bhayangkara Jakarta Raya. Universitas Bhayangkara Jakarta Raya. 